\title{
An Analysis of Moral Pursuit in Irish Murdoch's The Severed Head
}

\author{
Lei Zhang ${ }^{1}$ \\ ${ }^{1}$ School of Foreign Language Studies, Dalian Jiaotong University, Dalian, Liaoning 116028, China \\ *Corresponding author. Email: leiiris@163.com
}

\begin{abstract}
Modern men house potential meaning and value within themselves and their greatest social and political challenge is the exercise of consciousness through specific decisions that affirm and dignify the reality of other persons. Recreating a series of mythical characters and classical themes, Murdoch adjusts her moral philosophy to novelistic conventions and gains the success. This paper adopts myth and archetypal theory, analyses major characters and classical themes and interprets Murdoch's metaphorical attention towards the meanings of existence and the lost identity of modern men.
\end{abstract}

Keywords: value, political challenge, consciousness, moral philosophy

\section{INTRODUCTION-THE SCOPE AND COMPLEXITY OF IRIS MURDOCH'S FICTION}

Since the publication of her first novel Under the Net and its instant success, Iris Murdoc is becoming a versatile writer interested in a wide range of subject matters and profound themes and skillful in a variety of narrative technique choices in the contemporary British literary realm. Throughout her nearly-half-a-centurylong writing career, Iris Murdoch has been deeply influenced by many influential philosophers and their ideas in discussion of love, power, suffering, enchantment, psychology, religion and has become involved with almost all the important intellectual and political movements of the twentieth century: Freudian and Jungian psychology, existentialism, mysticism, transcendental realism and Neo-Platonism. She began with Under the Net, with what seems in retrospect a novel in the avant-garde mode of the 1950s, following a group of rootless characters in picaresque adventures around London as they try to develop some semblance of individual identities. In her second novel, The Flight from the Enchanter, some of the characters are less free than others, conditioned to a point of incapacity to choose by circumstances, nations, psyche, or history. Even among those for whom meaningful choice is possible, Murdoch maintains a difference between those who choose to exercise power over others, to "enchant," and those who build their identities, however trivial, to preserve the creature in resistance to various contemporary "enchantments". Subsequent novels expand the range of experience Murdoch treats and begins to question the value of the simple creature, the sanction of unconsciousness. In The Unicorn and The Time of the Angels, she adds dimensions of mystery and myth to her treatment of human identity and probes the meaning and value of religious experience.

Thus, Murdoch's numerous writings defend the integrity of the individual as a unique and unified center of value and significance. She explores the character of human existence with respect to the relation between self-consciousness - the mode of moral being - and the good. In this way, Murdoch retrieves themes within Platonic ethics in the context of contemporary culture[1]. In the late 1960s Murdoch's fiction becomes more directly and coherently ethical in focus. Her ethical framework provides a fairly consistent structure, a central debate and resolution worked through the usual Murdoch world of bizarre incident and predictably unpredictable encounters. In 1970s, Murdoch's fiction continues to suggest the range of human thought, the classically philosophical as well as the linguistic and ethical.

At the same time, she admires the great nineteenthcentury English and Russian novels. Thus, with her books, she longs to replicate the complex characterization and details. In her effort to recreate a 19th century style of fiction, Murdoch combines a variety of narrative techniques and forms, so that her novels usually contain the intrigue of a thriller, the twists of an adventure story, the dynamics of a romance tale, and the comic patterns of Shakespeare and Greek literature. 
Thus, Iris Murdoch establishes a prodigious body of reflective and philosophical work, a wide-ranging discursive and metaphorically conveyed commentary on the contemporary world.

\section{OVERVIEW OF TARGET WORK AND MAIN CHARACTERS}

A Severed Head tells about the first-person narrator Martin Lynch-Gibbon who undergoes a difficult lesson that forces him to come to accept and to love the otherness of other people, and his enlightenment is reflected in the experience of other characters as well. At the beginning of the novel, Martin, a wine dealer whose hobby is military history, is married to Antonia, a society beauty five years his senior who fulfills a veiled mother need for him. Meanwhile he conducts a very satisfying and discreet affair with Georgie Hands, a twenty-sixyear-old instructor at the London School of Economics. The first strong blow to Martine's complacency is Antonia's announcement that she wants a divorce because she has fallen in love with Palmer Anderson, an American psychiatrist of whom Martin is fond to the point of homosexual attachment. Despite his revulsion, Martin acquiesces in allowing Antonia to live with Palmer and remains friendly with the pair but to find that he is more in love with Antonia than ever. Then he escapes his dilemma by a Christmas visit to his sculptor elder brother Alexander. Alexander is at present working upon a realistic head, a work which depends for its model not upon reality but upon imagination. Later, Martin goes to the Liverpool Street railway station to meet Honor Klein, Palmer Anderson's half-sister, an anthropologist from Cambridge and she is the "severed head" of the title. Shortly afterwards, he takes Georgie back home where he has shared with Antonia but when he hears a key turning in the latch, Martin fiercely insists that Georgie flee by a back door, then Georgie's patience with him ends. Ironically, the intruder is not Antonia, but Honor Klein. Noting Georgie's handbag and books on the hall table, Honor goes immediately to Georgie, extracts the history of her affair with Martin. Later, Antonia knows everything, and the dramatic event and lover changing scene happens. At the end of the novel, the six characters reconstruct their relationship: Antonia leaves with Alexander, Georgie leaves with Palmer and Honor comes back to Martin.

\section{ARCHETYPAL INTERPRETATION OF DEMONIC IMAGERY-MORAL AND ARTISTIC DEFICIENCY}

The importance of the god and other mythical heroes in the myth lies in the fact that such character, who are conceived in human likeness and yet have more power over nature, gradually build up the vision of an omnipotent personal community and being considered as literary archetypes. They embody universal feelings that are widely shared among diverse cultures. Such crossculture models as the quest heroes, the outcast, the temptress, the scapegoat, the good mother, the old wise man and the trickster are frequently found in the world literature. These examples are by no means exhaustive but represent some of the more common archetypal images that we are likely to encounter in literature. This is also true of Iris Murdoch's major fiction. Meanwhile, Murdoch makes myths appear into her works by way of re-creating. Even if the narrative tone is a modern one, the novel employs typical motifs from the traditional myths. "The role of mythical motifs is analogical, describing the modern world in the light of a readily available set of models, works that are mythical do not offer myths as analogies, but make them their principal subject-matter or structural principle"[2]. Murdoch's psychological investigation of enchantment, demonic power and power-figure is reexamined and intensified in A Severed Head. Honor Klein richly qualifies as the "god figure" in the novel. She possesses an eerie power and authority that derives at least in part from the oriental exoticism of her appearance and her skill with the samurai sword. So she is described in images of hardness and sharpness. Her "curving lips are combined with a formidable straightness and narrowness of the eyes and mouth"[3]. She flashes Martin a "keen look" when he first speaks to the "haggard woman"[3]. Later, she actually slashes about with a "hideously sharp" Samurai sword[3]. Unlike the golden aura surrounding Antonia and Palmer, darkness frequently looms about Honor: she has "short black hair" and "narrow dark eyes" [3]. At one point her features remain Martin of a face in a "Spanish religious painting, something looking out of darkness, barbarous yet highly conscious" [3]. In one world, Martin tends to in his mind associate her with the "dark Gods" [3]. When they first meet each other at the hellish station, the didactic demon from Honor swiftly sets to work. When Martin tells Honor that her brother is at home and "he's got a cold. Nothing serious. I'll take you there at once" [3]. Honor's acid remarks are "this is an unexpected courtesy, Mr. Lynch-Gibbon" [3]. Only gradually does Martin realize the scorn behind her remarks. However, it indeed seems odd for a man to be running errands for his wife's lover.

Martin soon becomes aware that she haunts him. And several days later, Honor gives Martin a harsh lecture about the reprehensible softness with which he has treated the lovers: "By gentleness you only spare yourself and prolong this enchantment of untruth which they have woven about themselves and about you too"[3]. Shortly afterwards, Martin brings his mistress Georgie home but interrupted by a sudden key turning in the latch. Ironically and unexpectedly, the intruder is Honor Klein instead of his wife Antonia. Noting Georgie's handbag and books on the hall table, Honor again plays the dominant figure to Martin's embarrassed shame. She soon acts as a bridge between Georgie and Antonia and 
forces Martin to allow Georgie and Antonia their muchdesired confrontation. At this moment, Honor serves as a God-control Martin's mind and guides his action. She tries to use didactic comments and somewhat strange action to direct Martin. Martin is enchanted completely and willing to run after her. On New Year's Eve Martin calls at Palmer's residence where a "yellow sumptuous haze" encases the street lamps[3]. He finds the happy couple out, but comes across Honor Klein in the dinning room which seems so "abnormally dark" that Martin wonders if some of the fog has not drifted in. He soon realizes that Honor has lapsed into an extreme state, although he does not know the cause of her agitation. Certainly looking like a fiendish instructor, Honor sits at the head of the table with a sharp Samurai sword that she has removed from the dining room wall. As an expert with the weapon, she tells Martin that sword play in Japan is considered a spiritual exercise expressing control and power. Although the title of the book reverberates in various ways throughout the entire novel, one particular meaning is reinforced in this scene as Honor stands up and tosses first Antonia's and then Palmer's soiled dinner napkins in the air. Swiftly welding the mighty weapon, Honor "decapitates" each napkin and then looks down at the "severed" remains [3]. The dirty napkins represent Antonia's and Palmer's crumple gentility. As the demonic Honor Klein slashes the symbol of their civilized mentality, she creates for Martin a terrifying demonstration of naked power. The scene of the novel forcefully depicts the transfer of demonic energy to Martin. Martin, however doesn't immediately act upon the dark knowledge gained during this strange lesson. In fact, several evenings later while slightly drunk, he even seems to fall back into his submissive role as he serves wine to Antonia and Palmer in bed together in Palmer's exotic chambers. Showing that Honor's violent lesson has had some impact, Martin at least spills the wine, making a "big red stain [that] spreads on the white absorbent carpet" [3] and that represents his suppressed violence. As Martin stumbles into the basement with the rest of the case of wine, he is suddenly interrupted by Honor Klein, "looking down at [him] broodingly". The didactic taunting continues as she labels him "the knight of infinite humiliation" [3]. This time, however, the lesson hits home. Martin suddenly acts as if he is indeed possessed by a demon. He knocks Honor onto the cellar floor, jumps on her, and belts her across the face three times.

Although Honor struggles like "a maniac", her fiendish pupil cannot be overcome. Ultimately Honor teaches Martin to become a fighter as well, since no good can come from "letting people off"[3]. As the novel continuously progresses, the "alien God" insist on turning Martin himself into a demon in order to draw him out of Antonia and Palmer's erotic love fantasy and returning him to the "real world"[3]. Martin's education then resembles the underworld journey required of the mythic hero before he could reach his subconscious mind until he can discover true reality. And Honor Klein serves as Martin's hellish guide, an "alien God" controls his mind and direct his behavior.

\section{PLATO'S CAVE ALLEGORY}

Plato in his The Republic presents us the most beautiful and famous metaphor in western philosophy: the allegory of the Cave. This metaphor is meant to illustrate the effects of truth and reality on human souls, and brings human beings to the Good.

Plato's theory is notoriously difficult to grasp, and Murdoch's reading of Plato is precisely as difficult. She rewrites Plato's parable of the Cave, in which the prisoners are chained in such a way that they cannot see the sun, and mistake the fire-reflected images they so see for truth and reality. In fact, that is a false image and what he sees is not the truth. Murdoch applies this Platonic myth into her own novel A Severed Head, and from the analysis of protagonist Martin's experiences, we can get a glimpse of the symbolic cave and its prisoner.

"If you asked Francesca to describe her soul," Saki asserts in the Unbearable Bassington, "she would probable have described her living room"[5] So it is with the characters in A Severed Head. The narrator, Martin, and Antonia, his wife, are always willing to place objects carefully "in the rich and highly integrated mosaic of [their] surroundings," while Georgie is "destined not to possess things"[3]. In front of the candles on Georgie's mantelpiece, "as at an alter [3], Martin places his gift of a pair of Chinese incense-burners. In the half-light, Georgie and Martin gaze at each other. Deluding himself that he loves Georgie "infinitely" [3], Martin wisely accepts her wry emendation: "your love is a great but finite quantity" [3]. In the light of further revelations, Martin's "love" is further qualified: he has allow Georgie to have an abortion while underestimating the sacrifice that it constitutes for her, and he wishes to possess Georgie as his mistress while enjoying the possession of his beautiful wife Antonia. Ostensibly, he worships his "river Nymph" Georgie without giving up his adoration of another Goddess, Antonia[5].

Yet, the incense that Martin burns is essentially in honor of himself. Each ménage, both significantly lighted with firelight and candles, is a version of the Cave. In each, Martin makes icons of shadow-deities: himself and the women. Disclaiming any sort of religious belief on his part, Martin patronizingly describes Antonia's "creed" [3] as a "metaphysic of the drawing room" [3] that takes the form of an "undogmatic apprehension of an imminent spiritual interlocking where nothing is withheld, and nothing hidden" [3]. Martin knows that Antonia is knowingly the center of her cult; what he does not know until much later is that Antonia has withheld nothing from Palmer, her psychiatrist, and Alexander, her 
brother-in-law, but that she has certainly withheld the truth about these relationships from her husband. At the beginning, Martin perceives Antonia, with her greying gold hair and her great tawny eyes, as being "like some rich gilded object", which he is fortunate to possess[5].

The affair with Palmer, when discovered, causes Martin to extend his capacity for idol-worship to include yet another figure: Palmer. Martin supposes that he is reacting in a sophisticated and civilized way. He prides himself on suavely living up to Antonia's and Palmer's evident expectation that he will not only grant the divorce but continue to be a good friend to both of them. He accepts such a role with almost no qualms until Palmer's sister, Honor Klein, disrupts his satisfaction. Indeed, he has been enjoying his idolatry of the adulterous couple. In the "golden firelight" [3] of the drawing room of Palmer's house, yet another Cave, he sees the embracing couple, Palmer and Antonia, "each outlined with a pencil of Gold" [3]. Martin envisions them as being "like deities upon an Indian frieze, enthroned, inhumanly beautiful, a pair of sovereigns, distant and serene" [3].

By contrast, Honor appears to be a captain armed for battle, though Martin cannot imagine why. Her first scornful attack is not upon the idols but upon their worshipper, who is deluding himself in his civilized role: "you cannot cheat the dark gods" [3]. In the next section of the novel, Martin experiences "undirected sexual desire." His turning from the images to the fire is gradual. He still sees, or fancies that he sees in the empty fire lighted drawing room, some "tall shadow" [3] of Palmer and Antonia, but he is clearly ready to move away from the shadows; his is no sudden liberation. Murdoch shows Martin entering another room also lighted by candles, "a cave of warm dim luminosity" [3]. There is Honor Klein. Always the worshipper, Martin says: it was like an arrival at the shrine of some remote and self-absorbed deity" [3]. Palmer and Antonia have gone to the opera, which Murdoch identifies as the twilight of the gods. Honor herself is an alien god and she picks up a Samurai sword and cuts a napkin in two for Martin with the attitude of an executioner. Although she denies that she is attracted to the idea of decapitating people as a spiritual exercise, she affirms a connection between spirit and power. Martin is beginning to feel a powerful attraction to her [5].

Yet he returns once more to his old worship, again perceiving Palmer and Antonia as religious icons. The yellow-satin wallpaper is said to "flicker" in Martin's eyes; Antonia's hair is now "faded gold" [3], whereas the silver-haired Palmer becomes even more powerful: "like some casual yet powerful Emperor in a Byzantine mosaic" [3]. The scene is ambivalent: Martin ironically tells them they are Aries and Aphrodite, only to have Palmer retort, "you are not Hephaistos" [3]. Indeed not: Hephaistos captured his wife and her lover and exposed them to the other Olympians. Yet in The Iliad Hephaistos bustles about serving the nectar and ambrosia to the amusement of the handsomer deities; and Martin proceeds to emulate this role. As he tells them, he will serve them wine rather than attempting to kill them-a strange and imperfect communion, during which Martin spills wine and tries to eradicate the stain [5]. In the end, however, he is more worshipful ever and sees Antonia's gold head and Palmer's silver one on a white bed: "they glowed $[\ldots]$ out of a center of white and golden light [...as in] some rich reliquary or triptych" [3].

In the next scene, thoroughly drunk, Martin stumbles down the cellar steps, encounters Honor, seizes her like a different sort of cave dweller, and flights with her physically. Soon after, emerging literally into the sunlight, he gropes for understanding, perhaps even revelation, but none is forthcoming. Instead, by moonlight, he "discovers" [3] his love for Honor. He determines to seek her out, but when he finds her, he witnesses a "primal scene" [3] indubitably of lovers. She is in bed with her brother, Palmer. This is the turning point of the novel. Martin's love for Honor is a terrible love, no golden illusion, but a love "out of such depths of self as monsters live in" [3]. No wonder Martin feels accused. Murdoch compares him to a man who "has slept with temple prostitutes, and visited by a goddess, cannot touch a woman after" [5]. Much less the dilettante than before, Martin now acquires the mastery over Palmer. Although the myth of Gyges and Candaules, which Honor later reminds him of, seems to require that he kill Palmer, Martin merely assaults him: when Palmer seeks to reassert the old authority, Martin hits him in the face but subsequently decides that the action is horrible and ludicrous, revives him with whisky, and sends him home in a taxi. Ironically, the primitive battle wins him what he no longer wants-Antonia's return to him. Martin is by no means out of the Cave; rather, he is caught in a labyrinth.

\section{CONCLUSION}

Iris Murdoch certainly ranks among the greatest contemporary novelists in England today. Her fictional world is rich and ebullient. Though she does not like the label "philosophical novelist", her fiction expresses a discernible attitude towards human conduct, and her driving principle is an inquiry into moral values as they occur in daily life. For Murdoch, morality is not a divinely given truth, but a process which occurs when we respect the reality of other people. Literature provides the most essential and fundamental aspect of culture, because art presents the most comprehensible examples of the almost irresistible human tendency to seek consolation in fantasy and also of the effort to resist this and the vision of reality which comes with success. Thus the proper study of how to reach beyond egotism into the moral and artistic maturity in human situation is significant: to silence and expel self, to contemplate and delineate 
nature with a clear eye, is not easy and demands a moral discipline[6]. Literature also provides sense of human love, yet love and goodness are so mysterious that the unexamined life may be the most worth living and the simplest people are sometimes the best. She understands that all efforts to make life comprehensible require theories and ideas, and that raw experience is something merely occurs, containing in itself no positive values. Yet the traditional metaphysics is not close enough to finite experience to convey the reality of individuals. The external world exists independent of ourselves, and the selfless apprehension of it is a very difficult task.

\section{REFERENCES}

[1] I. Murdoch, "the Search for Human Goodness". Chicago and London: The University of Chicago Press, 1996.

[2] J. J. White, "Myth and the Modern Novel." Literary Criticism and Myth. Ed. Robert. A. Segal. New York and London: Garland Publishing, Inc, 1996.

[3] I. Murdoch, A Severed Head. Harmondsworth: Penguin Books Ltd, 1961.

[4] Plato. The Republic. London: Oxford University Press, 1993.

[5] A. Gossman, "Icon and Idols in A Severed Head." Iris Murdoch: Modern Critical Views. Ed. Harold Bloom. New York: Chelsea House Publishers, 1986.

[6] I. Murdoch, The Sovereignty of Good. London: Routledge \&Kegan Paul, 1970. 